\title{
ZsuZsanna Csikós
}

\section{JUAN CARLOS ONETTI: LA CASA EN LA ARENA Análisis narratológico y semiótico}

\section{Prólogo}

El relato del autor uruguayo, escrito en 1949, nace como uno de los capítulos de la novela $L a$ vida breve y primitivamente se publica como fragmento de ésta. Sin embargo, la edición definitiva de la novela, publicada un año más tarde en Buenos Aires, no incluye este capítulo. La casa en la arena cobra vida propia y forma parte del primer libro de cuentos de Onetti, Un sueño realizado y otros cuentos que sale a la luz en 1951.

Estos antecedentes ofrecen muchos puntos de contacto entre las dos obras. La ciudad de Santa María y la figura del médico, Díaz Grey, protagonista del relato, nacen en la fantasía de Brausen, protagonista de La vida breve. "Tenía ahora la ciudad de provincia sobre cuya plaza principal daban las dos ventanas del consultorio de Díaz Grey" - son las palabras de Brausen al imaginar en su mente una de sus vidas breves. "Cuando Díaz Grey, en el consultorio frente a la plaza de la ciudad provinciana se entrega al juego de conocerse a sí mismo mediante este recuerdo..." - leemos en La casa en la arena.

En la novela existen alusiones también a Quinteros -otro personaje del relato-y sus relaciones con el médico: "Quinteros - dijo- (Díaz Grey). Sí. Fuimos muy amigos. Supe que se había especializado en enfermedades nerviosas y que era socio o dueño de un sanatorio. Tuvo suerte. Tuvo además la voluntad de quedarse en Buenos Aires, el coraje o la insensibilidad necesarios para soportar tantas cosas." ${ }^{3}$

En la novela Elena Sala viene al consultorio de Díaz Grey para recetar morfina por consejo de Quinteros. En el cuento él y Díaz Grey negocian con recetas de morfina.

El enlace más profundo se descubre a propósito del capítulo Los desesperados de la novela. No solamente por el paralelismo de las diferentes variantes de las historias tratadas en este capítulo y en el cuento, sino por encontrar la clave del código ideológico del relato - de lo que hablaré al final del análisis- en el monólogo del obispo sobre los desesperados en este capítulo de la novela. La desesperación, es la que une la historia de Elena Sala (también ella es una de lás invenciones de Brausen) de la novela con la de Díaz Grey del relato. Ambos son desesperados por excelencia. ${ }^{4}$ Elena Sala se enamora de un joven inglés y cuando éste desaparece, su vida se convierte en una obsesiva búsqueda de este hombre a través del constante recuerdo. Sobre las

1 J. C. Onetti: La vida breve, Editorial Sudamericana, Buenos Aires, 1968, p. 20.

2 J. C. Onetti: La casa en la arena, Obras completas, México, Aguilar, 1970, p. 1247.

3 J. C. Onetti: La vida ..., p. 43.

4 Véase más detalladamente: Kulin Katalin: «Onetti y el existencialismo», in: Actas del Congreso Internacional de A.E.P.E., Budapest, 1980, p. 114. 
causas de la desaparición del hombre el marido de Elena, Horacio Lagos, cuenta distintas versiones a Díaz Grey .

En La casa en la arena Díaz Grey se enamora de una joven inglesa, y de su historia de amor el médico "hace un verdadero culto de las variantes posibles de la memoria". 5

Estos ejemplos son las primeras demostraciones de la intertextualidad en la narrativa onettiana: a propósito del mito de Santa María y de sus habitantes nace "...un complejo sistema intertextual en una comunidad privada, la ciudad junto al río, se imbrican unos en otros, se entrecruzan, aluden, iluminan, completan y corrigen como si fueran fragmentos de una totalidad."6

En el análisis de La casa en la arena principalmente aplicaré algunas de las categorías del modelo narratológico de Mieke Bal completándolas con ciertos códigos semiológicos.

\section{Los acontecimientos}

Los acontecimientos del relato se estructuran en dos niveles narrativos: el primero narra la historia de un recuerdo, el otro consta de su permanente evocación por parte de Díaz Grey, donde la realidad y la invención se mezcla.

Díaz Grey, el médico, receta morfina para Quinteros quien negocia con éstas. Por la participación en el negocio prohibido, el doctor tiene que dejar la ciudad y va a la casa de campo de Quinteros. Más tarde llega Colorado, un "semiidiota pelirrojo"8 a quien manda Quinteros y después Molly, la amante inglesa de éste. Díaz Grey se enamora de Molly, y recibe un anillo de la chica. Sin embargo, por su parte, Colorado quiere impedir esta relación amorosa. Después de arreglar el asunto de la morfina Quinteros vuelve a la casa en la arena para recoger a Molly. Díaz Grey queda solo con Colorado quien incendia la casa con la ayuda del médico.

En el nivel del recuerdo - que parece ser una simple historia de amor- apenas hay diferencia entre la fábula y la historia (entre el orden cronológico de los acontecimientos y su aparencia en el texto). El único desvío cronologico hace conocer la causa del "exilio" de Díaz Grey que se aclara después de su llegada a la casa en la arena. Hay una aparente linearidad de los sucesos en el relato.

Los momentos de la constante evocación vienen intercalados en los acontecimientos del recuerdo. Díaz Grey juega con él: en parte piensa en lo realmente sucedido, en parte inventa posibles variantes.

"Veía las imágenes del recuerdo y se veía a sí mismo al transportarlo y corregirlo para evitar que muriera, reparando los desgastes de cada despertar, sosteniéndolo con imprevistas invenciones..."

5 Expresión utilizada por Fernando Aínsa en su ensayo titulado «El amor como búsqueda imposible de la perfección», in: Cuadernos Hispanoamericanos, diciembre de 1974, p. 203.

6 J. C. Onetti: Novelas y relatos. Prólogo de Hugo Verani. Biblioteca Ayacucho, Caracas, 1976, p. XVIII.

7 Las dos fundamentales obras teoréticas son: Mieke Bal: Teoría de la narrativa. Una introducción a la narratología. Madrid, Cátedra, 1987; Análisis textual semiótico in: Fundamentos del análisis literario, III. capítulo, Madrid, p. 262-369.

8 J. C. O.: La casa ..., p. 1239.

9 Ibídem, p. 1237. 
La sensación del perfume de la mujer es el momento propiciador para la narración: une el pasado remoto (el recuerdo) con la pasión presente (evocación).

"Descubriría entonces que el Colorado, la escopeta, el violento sol, la leyenda del anillo enterrado, los premeditados desencuentros en el chalet carcomido y aun la fogata final, estaban ya en aquel perfume de marca desconocida que ciertas noches, ahora, lograba oler en la superficie de las bebidas dulzonas."10

El segundo nivel -el de la rememoración - da el marco al relato: algunas frases del primer párrafo y del penúltimo - Díaz Grey en su consultorio y su rito- coinciden y constituyen los únicos puntos fijos de la narración.

Es posible estructurar los acontecimientos también en secuencias si seguimos el modelo semiótico de Claude Bremond. Según su definición las secuencias son series lógicas de nudos del acontecer, remesas que se suman en la partida total de la anécdota. ${ }^{11}$ Las tres secuencias del relato responden a las tres fases de la evocación ${ }^{12}$ y son bien ubicables dentro de la unidad tríptica de la soledad - amor- fatalidad -que está profundamente ligado a la idea de la muerte-, propia de la narrativa onettiana . La primera abarca los acontecimientos hasta la llegada de Molly a la casa; la segunda une los momentos de la relación de Díaz Grey y Molly; la tercera, la leyenda del anillo enterrado, la desaparición de Molly y la fogata final.

El recuerdo - a través de la constante evocación- pasa a ser un mito para el médico.

\section{Actores, Actantes, Personajes}

Los actores del relato son cuatro: Díaz Grey, Molly, Colorado y Quinteros. La figura siguiente trata de dar el esquema de las relaciones actanciales a nivel del recuerdo.

Figura I.

\begin{tabular}{|llll|}
\hline $\begin{array}{l}\text { Molly } \\
\text { dador }\end{array}$ & $\begin{array}{l}\text { Molly } \\
\text { objeto }\end{array}$ & $\Rightarrow$ & $\begin{array}{l}\text { Díaz Grey } \\
\text { receptor }\end{array}$ \\
$\begin{array}{l}\Uparrow \\
\text { no hay } \\
\text { ayudante }\end{array}$ & $\begin{array}{c}\text { Díaz Grey } \\
\text { sujeto }\end{array}$ & $\Leftarrow$ & $\begin{array}{l}\text { Colorado (Quinteros) } \\
\text { oponente }\end{array}$ \\
\hline
\end{tabular}

Las funciones de los actores -excepto la mujer- son bien definibles: el objeto de Díaz Grey es Molly. En esta relación el objeto y el dador son la misma persona. Al

10 Ibídem, p. 1237.

11 Sobre el modelo de Bremond véase: Garrido Domínguez, Antonio: El texto narrativo. Madrid, Editorial Síntesis S. A., 1993, p. 47-49.

12 Las tres fases están explícitamente indicadas en el texto: en el principio del recuerdo (p. 1237); aquí se inician los momentos que alimenta al resto del recuerdo (p. 1241); en el final preferido para su recuerdo (p. 1247). 
mismo tiempo, la función de Molly parece ser pasiva no se sabe nada sobre sus metas (sujeto-objeto).

Colorado es un hombre pirómano, tanto en su presencia como en su comportamiento se parece al perro. Su función es también semejante: vigilar y guardar a Díaz Grey y a Molly. Él es el lugarteniente de Quinteros, representa sus intereses en su nivel mental que corresponde a un animal (perro). Él trata de impedir el amor del médico con Molly. En este sentido su relación actancial es oponente.

La función de Quinteros es arreglar el asunto de la morfina, función que no se cruza con la de Díaz Grey, sino que corre paralelamente. A pesar de ser el amante de Molly, aparentemente queda fuero de lo que sucede entre los tres personajes. En realidad, su influencia indirecta en los acontecimientos queda bien clara: él manda tanto a Colorado como a Molly a la casa. No quiere perder a la mujer: para salvarla la retira del asunto de la morfina, y con la ayuda del Colorado trata de guardarla para sí mismo. Las palabras de Quinteros y Molly justifican esta relación triangular:

"--Se arreglará -dijo Quinteros-. ¿No es cierto que te arreglarás? Dos o tres días.

Elia alzó la cabeza para mirar a Quinteros.

- Tengo al Colorado para que me cante.

-Ella te explicará, si quiere - dijo Quinteros-."13

Cuando viene a recoger a la mujer, Molly enseguida lo sigue como si no hubiera pasado nada entre élla y el médico: "Ella ve el automóvil antes que Díaz Grey y se echa a correr, resbalando en la arena. El médico la ve subir a una duna, los brazos abiertos, perder pie y desaparecer. "14

A nivel de la evocación, el esquma es el siguiente:

Figura II.

\begin{tabular}{|llll|}
\hline $\begin{array}{l}\text { el perfume de la mujer } \\
\text { dador }\end{array}$ & $\begin{array}{c}\text { invención } \\
\text { objeto }\end{array}$ & $\begin{array}{l}\text { Díaz Grey (Colorado) } \\
\text { receptor }\end{array}$ \\
la fantasía & Díaz Grey & $\begin{array}{r}\text { la realidad/el nivel del } \\
\text { recuerdo }\end{array}$ \\
ayudante & $\Rightarrow$ & sujeto & $\Leftrightarrow$ oponente \\
\hline
\end{tabular}

Díaz Grey a través de la constante evocación y las alternativas formentadas por el recuerdo quiere inventar una vida nueva: busca su razón de ser. Otra vez, volvemos a La vida breve: Brausen inventa varias vidas breves para cobrar otra personalidad.

Según el modelo actancial de C. Bremond la estructura del relato viene determinada por el conjunto de roles que traducen "... el desarrollo de una situación general sobre la cual actúan y por la cual son afectados." $\mathrm{El}$ agente y el paciente son los dos

13 Ibídem, p. 1242.

14 Ibídem, p. 1246.

15 Garrido, ibídem, p. 51-52. 
papeles básicos: a nivel del recuerdo en el cuento onettiano Quinteros es el único personaje agente influenciador, los demás (Díaz Grey, Molly y Colorado) son pasivos. En ellos es común la incapacidad para actuar, se parecen a "un madero carcomido balanceado por las olas". ${ }^{16}$ Quinteros manda a los tres a la casa en la arena, e indirectamente él es el provocador de los acontecimientos que suceden en aquel lugar.

Otro rasgo característico común de los tres personajes es que son seres marginados. Molly es una mujer extranjera, "...habla en inglés a nadie". ${ }^{17} \mathrm{El}$ estado mental de Colorado (semiidiota) le coloca también al margen de una sociedad convencional. En el caso del médico se trata del rechazo voluntario de esta misma sociedad, es decir, se trata de un "exilio voluntario".

En el relato tanto la identificación de Molly como la del Colorado corresponde a lo olfativo.

"Díaz Grey reconoció el perfume, supo que ella se llamaba Molly... Díaz Grey comprendió, emocionado, que ella había sido capaz de descubrir, con una sola mirada, tal vez por el olor, que el Colorado había sido transformado en perro.",18

A nivel de la evocación el agente y el paciente son el mismo personaje, el médico. La constante rememoración e invención son uno de los métodos de autoconocimiento, a través de lo cual el protagonista trata de encontrar una salida de su desesperación.

El descubrimiento del mismo sentimiento en la cara de Molly despierta el amor de Díaz Grey hacia la mujer. La conocía antes, pero no significaba nada para él, ni siquiera sabía su nombre exacto: era simplemente la amante inglesa de Quinteros, Dolly o Molly. Sin embargo, el amor que parece ser un sueño realizado"19 en las obras onettianas jamás durará más que un instante: "...apenas se lo ha descubierto está ya depositado en él la semilla de su acelerada destrucción. ${ }^{20}$

Molly, al ver a Quinteros, desaparece tan pronto e inesperadamente como ha llegado.

"El médico la ve subir a una duna, los brazos abiertos, perder pie y desaparecer; queda solo ante el pequeño desierto de la playa, los ojos lastimados por el viento."21

Es bastante contradictoria la relación de Díaz Grey y Colorado. El médico siente piedad y repulsión hacia él al mismo tiempo. En un momento dado le acaricia la cara, en otro, decide matarlo. Estos sentimientos ambiguos vienen de la semejanza de estos dos personajes, sin embargo, sus "yoes" pertenecen a diferentes niveles. Ambos son seres solitarios, pero la soledad del médico es una racionalidad, una postura que él mismo elige. En el caso de Colorado se trata de un instinto animal: él parece mucho a un perro. Esta metamorfosis está presente tanto en su aspecto como en su comportamiento: anda descalzo, se estremece como un perro mojado, su tarea es inspeccionar y vigilar su ambiente, guarda la chimenea apagada, Díaz Grey le llama con un silbido etc. Sus sentimientos quedan expresadas también en el mismo nivel: siempre va acompañado de una escopeta la que cree el símbolo de la fuerza y virilidad.

16 La casa ..., ibídem, p. 1238.

17 Ibídem, p. 1245.

18 Ibídem, p. 1241.

19 Me refiero al título de otro cuento onettiano: Un sueño realizado (1941).

20 Fernando Aínsa, ibídem, p. 195.

21 La casa ..., ibídem, p. 1246. 
Colorado es un hombre pirómano, está enamorado del fuego. Él cree que al tratar de identificarse con el sol es capaz de oponerse a su inmolación. ${ }^{22}$ En la mitología la relación del fuego con el sol toma cuerpo en la figura del ave fénix, palabra de origen griega, que significa rojo, lo mismo que el nombre del Colorado. El fuego —entre otras cosas- representa el amor también, o sea, en el caso del médico y Colorado se trata de la expresión del mismo sentimiento en sus niveles correspondidos.

Díaz Grey, al ver a Colorado, primero se da cuenta de la sombra de éste, como si fuera su propio apéndice. Con la llegada de Colorado parece que nada cambia.

"Él no está", pensaba Díaz Grey mirando el cuerpo encogido y silencioso del Colorado.,23

La sonrisa del Colorado en la que el médico revela "la larga espera de un milagro imposible",24 bien podría ser su propia mirada desesperada, la búsqueda del sentido de la existencia. ${ }^{25}$

"Parece existir, pues, una progresiva reducción de las alternativas que el futuro ofrece a Díaz Grey en relación de la adecuación a las anticipaciones del pasado, así como una aceptación fatalista de su destino impuesta por la presencia del extrano testigo: el guardián Colorado-" escribe en su ensayo José Ortega. ${ }^{26}$

Antes de la llegada de Molly, Colorado con sus pasos indica de antemano los sitios en que sería enterrado el anillo por Díaz Grey, y parece comprender los sentimientos del médico después de la desaparición de la mujer:

"Tan dramáticamente como si quisiera convencer de que lo ha comprendido todo antes que Díaz Grey, el Colorado se incorpora y vuelve hacia la puerta, hacia la lluvia que cede, una cara humanizada por la sorpresa y la angustia. Toca al médico por primera vez, le aferra un brazo y parece fortalecerse con el contacto: después se levanta y sale corriendo de la casa.",27

En la última escena del recuerdo el médico ayuda al Colorado a encender la casa: esta fogata final representa su destino común.

Díaz Grey “...respira el olor del keroseno inmoviliza al otro con un silbido imperioso y se le acerca, resbalando sobre la humedad y las hojas, saca del bolsillo la caja de fósforos y la sacude junto o un oído mientras avanza y resbala." ${ }^{28}$

El desdoblamiento del yo está presente en ambos niveles narrativos: en el del recuerdo Quinteros se identifica con Colorado; en el de la rememoración con Díaz Grey.

22 Ibídem, p. 1239.

23 Ibídem, p. 1240.

24 Ibídem, p. 1240.

25 Véase: Kulin Katalin: «El libro de Job y la obra de J. C. Onetti», in: Annales Universitatis, Sectio Philologica Moderna, Tomus XI, Budapest, 1980, p. 109-115. Kulin Katalin escribe: "La existencia cerrada es un motivo recurrente en las obras de Onetti para quien la principal metáfora de la vida es la trampa de donde es vano buscar salida." (p. 113.)

26 José Ortega: «La temporalidad en cuatro relatos de Juan Carlos Onetti», in: Cuadernos Hispanoamericanos, diciembre de 1974, p. 350.

27 La casa ..., ibídem, p. 1247.

28 Ibídem, p. 1248. 


\section{Tiempo}

\section{a.) Orden}

La fuerza transformadora de la constante evocación del recuerdo influye sobre todo en la percepción del tiempo. El orden cronológico lineal de los acontecimientos del relato es aparente, en realidad, se trata de un juego libre con el tiempo a través de la memoria. Todo el cuento se caracteriza por una anacronía subjetiva que algunas veces pasa hacia la acronía: es imposible definir el lapso y la distancia temporal.

Las secuencias de los acontecimientos están agrupadas por criterios climáticos. Hasta la llegada del Colorado todos los sucesos caben en un día de sol ardiente; después de su llegada "...se iniciaron los días de lluvia, un período de nieblas..." de la llegada de Molly el pedazo del recuerdo se extiende en una tarde lluviosa.

Los adjetivos de la tarde -eterna e inmóvil-, los versos escritos por Molly identificación de la casa con la idea de la muerte y la tumba- aluden también a la acronía.

La suspensión del tiempo sirve para eternizar el momento privilegiado del amor. Cuando Díaz Grey llega hasta el momento de la desaparición de Molly en la evocación, menciona: "...nuevamente el tiempo puede ser utilizado para medir."

De los tres aspectos de la desviación cronológica - dirección, distancia, lapsosolamente el primero es definible en este relato. La evocacion corresponde a un analepsis interno e iterativo: la costumbre de Díaz Grey se narra una sola vez. El prolepsis del segundo párrafo del texto, según lo cual el perfume de la mujer "...contenía y cifraba todos los sucesos posteriores" 31 , alude a una fatalidad propia del modo de pensar existencialista, anula cualquier tipo del suspense. Cuando todavía está solo, anticipa imágenes, que después de encontrarse con Molly se realizan, sin embargo, esta "realidad" existe solamente en su imaginación (ficción doble).

"Estaba, ... inventando, entre tantas otras cosas, un madero carcomido balanceado por las olas y un terceto de gaviotas chillando encima."

"Ahora sí hay, cerca de la costa, un madero podrido que las olas alzan y hunden; hay un terceto de gaviotas y su escándalo revoloteando en el cielo."32

La realidad y la fantasía se mezcla en la evocación: hay unas partes recordables y otras imaginadas, ambas con muchos variantes. Los cambios en el uso de los tiempos verbales del texto indican claramente esta alteración. El relato empieza en pretérito lo recordado-; a partir de la llegada de Molly la narración sigue en presente - lo imaginado-: aparece la doble ficción.

29 Ibídem, p. 1240.

30 Ibídem, p. 1247.

31 Ibídem, p. 1237.

32 Ibídem, p. 1238. y 1245. 


\section{b.) Ritmo}

Los cinco movimientos que regulan el ritmo narrativo reciben los nombres de elipsis, resumen, escena, pausa y deceleración en la terminología de Mieke Bal. ${ }^{33}$

En este cuento se alternan resúmenes, pausas (descripciones) y escenas. Hay escena siempre que aparece Quinteros. Él da cierta información a propósito del asunto de la morfina y desaparece. Sus actuaciones apoyan las partes recordadas del relato. En la mayoría de las escenas tenemos a un solo interlocutor, apenas hay "verdaderos" diálogos. En las partes anteriores a la llegada de Molly domina el resumen -concentración de los acontecimientos-, en las posteriores, las descripciones que sugieren también la interrupción del flujo del tiempo.

\section{c.) Frecuencia}

La frecuencia de una obra indica la relación numérica entre los acontecimientos en la fábula y en la historia. En este caso, la constante evocación del recuerdo, como un acto ritual, se presenta en una sola vez, pero con detalle: la frecuencia es de tipo iterativo que supone la mediación de subjetividad, por parte del narrador.

Son varios los motivos recurrentes del relato. El fuego, el anillo, la arena están relacionados con el tiempo y el destino: el fuego, entre otras cosas, representa su destrucción. Sin embargo, es inseparable de cierta fuerza renovadora. La fogata final del cuento - fuera de aceptar por parte de Díaz Grey su destino común con Colorado- contiene esta dualidad. El médico deja aniquilar las reliquias de su amor (fuerza destructora), además, el fuego tiene la capacidad de desodorización: todo lo purifica porque suprime los olores nauseabundos. ${ }^{34} \mathrm{Al}$ mismo tiempo, trata de eternizar los momentos privilegiados relacionados a Molly.

El anillo es el símbolo de la continuidad, totalidad, emblema del tiempo en eterno retorno. La escena del entierro del anillo ocho veces significa el intento fracasado de Díaz Grey para evitar la fatalidad de la vida.

$\mathrm{La}$ arena simboliza lo infinito y lo fugitivo.

\section{Lugar y espacio}

El mismo título del relato — que alude al lugar del recuerdo- es un topónimo: la casa en la arena. Tanto la arena como la casa -es suficiente pensar en el poema de Molly - se relaciona con el flujo del tiempo y la idea de la muerte. El incendio que hace desaparecer la casa refuerza más la parte ficticia del relato.

Los lugares de la invención, el consultorio y el bar del hotel son sitios cerrados que coinciden con la existencia real. Se trata -como hemos mencionado en la introducción- de Santa María: el consultorio se encuentra "frente a la plaza de la ciudad provinciana". ${ }^{35}$

33 Véase más detalladamente en Mieke Bal, p. 76-85.

34 Omar Prego y María Angelica Petit: «El juicio final», in: J. C. Onetti, Edición de Hugo J. Verani. Madrid, 1987. Los autores del ensayo citan a Gastón Bachelard, quien ha señalado la relación entre el fuego y lo olfativo. p. 382.

35 La casa ..., p. 1247. 
La descripción del paisaje del recuerdo en este caso es un signo de los personajes: se refiere a su mundo interior, o, expresado con otras palabras, la naturaleza se humaniza.

"Estaba, en el mismo día casi ardiente, bañándose en la completa soledad de la playa..." ${ }^{36}$-resume el médico su estado de ánimo antes de la llegada de Molly.

Los momentos fugaces de la felicidad se extienden en una tarde lluviosa, vivido en el interior de la casa.

"El ruido del agua se hace furioso en el techo y en el follaje, se gasta; ahora ellos andan en el silencio expectante, escudriñando el paisaje gris desde las puertas y las ventanas, remedando ademanes de estatua en la galería, un brazo estirado, todos los sentidos juntos en el dorso de la mano." ${ }^{37}$

Genette subraya la mutua dependencia entre la narración y descripción: la primera insiste en la dimensión temporal y dramática del relato; la otra implica el estancamiento del tiempo a través del realce del espacio y de la presentación de los procesos como auténticos espectáculos. ${ }^{38} \mathrm{En}$ el relato de Onetti el uso abundante de los verbos, como ver, mirar, justifican esta afirmación: los sucesos se convierten en imágenes.

\section{Narrador y focalización}

Los acontecimientos se relatan por un narrador aparentemente heterodiegético que, a primera vista, parece ser muy objetivo: se reduce a lo visto y perceptible. Sin embargo, esta objetividad es muy enganadora ya que se trata de transmitir ideas de una conciencia (lo interior), todo lo que se narra, sucede en la mente de Díaz Grey. De este punto de vista se parece a un narrador de primera persona (narrador autodiegético).

El narrador hace conocer solamente las ideas del médico: como él evoca y reelabora el recuerdo, o sea, la conciencia de Díaz Grey es la única fuente de información del cuento.

La objetividad aparente se modifica por el lenguaje, principalmente, por mediación de adjetivos se hace palpable la verdadera subjetividad del relato.

La focalización es variable: pasa del así llamado narrador objetivo al médico protagonista y al revés. Se da así un cambio del focalizador externo al interno - focalizador personaje-. La combinación de las diferentes perspectivas revelan la presencia activa del narrador. La focalización del médico se presenta dentro de la del narrador y el resultado de este procedimiento es que en algunos casos el sujeto y el objeto de la focalización coinciden.

"Veía las imágenes del recuerdo y se veía a sí mismo al transportarlo y corregirlo para evitar que muriera... No necesitaba agregar un solo minuto para verse conversar con los pescadores en la extremidad izquierda de la playa... verse recorriendo la orilla en dirección al pueblo..."39

Muchas veces el objeto de la focalización visto desde dos perspectivas diferentes muestra que la percepción de la realidad depende de punto de vista adoptado en cada

36 Ibídem, p. 1238.

37 Ibídem, p. 1244.

38 Garrido, ibídem, p. 221.

39 La casa ..., ibídem, p.1237 y 1238. 
caso. Las variantes diversas del recuerdo también sirven para subrayar la multiplicidad de la realidad. Me refiero a las frases de tipo siguiente: "Aquí se inician los momentos que alimentan al resto del recuerdo y le otorgan un sentido variable;" o "en el final preferido para su recuerdo..." etc. ${ }^{40}$

La focalización tiene un fuerte efecto manipulador -menciona Mieke Bal. ${ }^{41}$ En este caso todo el contenido del relato corresponde a las palabras no habladas, todo lo contado sucede en la mente del médico. Todos los actos "reales" e imaginados son manipulados, reforzando así el carácter ficticio del cuento.

\section{El discurso narrativo - Registros del discurso}

Genette distingue tres grandes categorías dentro del discurso del personaje. Estas categorías corresponden a las de Mieke Bal, sin embargo, los términos utilizados son diferentes. El discurso narrativizado, el discurso transpuesto y el restituido genettiano son idénticos a las formas de la enunciación del narrador, estilo indirecto libre y estilo directo de Bal. ${ }^{42}$

El modo narrativo del relato sugiere también la dualidad realidad/ficción del recuerdo. Los pensamientos de Díaz Grey se reproducen en el texto menos mimético del narrador. Los diálogos - son pocos - apoyan las partes reales del recuerdo. De los cuatro personajes es Quinteros quien siempre se expresa directamente. Así se acentúa su falta de participación en el nivel de la evocación.

De las cuatro modalidades principales de los registros del discurso del análisis semiológico - el abstracto, el valorativo, el connativo y el figurado- abundan estos dos últimos. El relato está lleno de metáforas y de varios ejemplos de adjetivación. Los olores, los colores, el clima cambiante transmiten situaciones, ambientes, sentimientos, actitudes emotivas: "bañándose en la completa soledad de la playa"; "el ruido del agua se hace furioso en el techo"; "las nubes se desgarran"; "sostienen la luz triste de la eterna tarde" etc.

La escasez de lo abstracto y de lo valorativo muestra también la falta de voluntad del médico para elegir y evaluar las diversas alternativas de sus "recuerdos".

\section{Códigos paraliterarios}

Por lo tanto, los códigos temático e ideológico son entidades abstractas: el tema, las ideas y los valores que una obra literaria trata de sugerir jamás se presentan en forma explícita. ${ }^{43}$

El tema - la fatalidad despiadada que controla la vida - y la ideología existencial de este relato onettiano aluden al hombre como ser solitario, indefensivo, desesperado quien busca en vano el sentido de su existencia. Plantea la angustia sufrida ante la imprevisibilidad, el desamparo, el absurdo de la existencia humana. La desesperación,

40 Ibídem, p. 1241 y 1247.

41 Mieke Bal, ibídem, p. 115.

42 Ibídem, p. 140-147 y Garrido, ibídem, p. 253-254.

43 Sobre el tema véase Análisis textual ..., p. 327-349. 
esta condición general, proviene de la impureza del yo de todos los hombres. ${ }^{44}$ En el capítulo ya mencionado de La vida breve el obispo habla de tres tipos de los desesperados.

"Existe el desesperado puro, lo sé. Pero no lo he encontrado nunca... lo imagino desposeído de todo, abrumado por lo que él llama desgracia, incapaz de erguirse hasta la altura de su prueba."

"Porque aparte de éste no hay más que el desesperado débil y el fuerte; el que está por debajo de su desesperación y el que, sin saberlo, está por encima... El desesperado débil muestra su falta de esperanza con cada acto, con cada palabra."

"Porque el desesperado fuerte, aunque sufre infinitamente más, no lo exhibirá. Sabe o está convencido de que nadie podrá consolarlo. No cree en poder creer, pero tiene la esperanza él, desesperado, de que en algún momento imprevisible podrá enfrentar su desesperación, aislarla, verle la cara.",45

Díaz Grey pertenece a este último grupo. Está consciente de la realidad inauténtica que condiciona su limitación existencial. La constante evocación forma el proceso de autoconocimiento más y más adentrado. El médico trata de evitar la fatalidad, busca la posibilidad de vivir una vida auténtica y perfecta, y busca refugio en el reconstruir este recuerdo cursi.

"También le es forzoso suponer que su vida meticulosa, su propio cuerpo privado de la lujuría, sus blandas creencias, son símbolos de la cursilería esencial del recuerdo que se empena en mantener desde hace años."46

En el código paraliterario respecto al contexto político-social esta desesperación representa el escepticismo común de la burguesía de una generación sin fe a partir de las primeras décadas del siglo veinte.

\section{Epilogo}

La historia del relato analizado comienza con La vida breve y termina con Dejemos hablar al viento, novela publicada en 1979.

Esta última cierra la saga de Santa María: es arrasada por el fuego. Vuelven las figuras del relato: Díaz Grey, Quinteros y Colorado. Éste último, por fin, incendia la ciudad, es decir, la fogata final es el desenlace común de ambas obras.

En la novela hay alusiones concretas a los sucesos del cuento. Una vez, cuando Díaz Grey conversa con Medina - protagonista de la novela- evoca sus recuerdos sobre Colorado.

“-Doctor - preguntó Medina, al despedirse-. ¿Usted conoce a un sujeto al que llaman el Colorado? Lo he visto merodear por aquí. Y algo me dijeron.

-Oh, historia vieja. Estuvimos un tiempo en una casa en la arena. Tipo raro. Hace de esto muchas páginas. Cientos."47

44 Kulin Katalin tiene algunos ensayos a propósito de este tema. Ella hace una comparación entre la filosofía onettiana y la de Kierkegaard y busca puntos de coincidencia con el Libro de Job. Véanse los dos ensayos ya mencionados y su libro titulado Esszék latinamerikai regényírókról, Szeged, 1993, p. 38-65.

45 La vida breve, p. 196.

46 La casa ..., p. 1247.

47 Lo cita Hugo Verani en: J. C. Onetti: Obra selecta, Prólogo, cronología y bibliografía Hugo Verani, Biblioteca Ayacucho, Caracas, 1976, p. XXX. 
La intertextualidad del epílogo y los semejantes ejemplos mencionados en la parte introductoria refuerzan el carácter coherente y cerrado de las obras onettianas. Sus novelas y relatos siempre vuelven a los mismos temas, a los mismos personajes, a los mismos motivos que radican en su filosofía existencial, según la cual "toda la ciencia de vivir está en la sencilla blandura de acomodarse en los huecos de los sucesos que no hemos provocado con nuestra voluntad, no forzar nada, ser, simplemente, cada minuto." $" 48$

48 Citado en Las trampas de Onetti por Fernando Aínsa Montevideo, 1970, p. 15. 
CSIKÓs ZsUZSANNA

Juan Carlos Onetti: La casa en la arena (Ház a homokon)

Juan Carlos Onetti uruguayi író elbeszélése 1949-ben készült, eredetileg a La vida breve (A rövid élet) címü regénye egyik fejezeteként. Később azonban mégis kimaradt belöle és önálló alkotásként kelt életre. Kapcsolata a regénnyel azonban számos ponton fellelhető: az Onettire oly jellemző intertextualitás számos példájával találkozhatunk ebben a müben is.

Az elbeszélés főszereplōje az egyik állandó Onetti-hős, az orvos Díaz Grey, akinek életét egy emlék állandó felidézése és számos lehetséges variációjának kitalálása tölti ki. Ezáltal a valóság és fikció világa összemosódik. Két narratív szinten futnak az események: az első szintet az emlék történései a másodikat a felidézés és a kitalációk alkotják.

Maga az emlék egy egyszerủ szerelmi történetnek tünik Díaz Grey, és Quinteros angol szeretője, Molly között. Az elbeszélés mélystruktúráját tekintve azonban sokkal fontosabb a negyedik szereplő, a félőrült piromán ember, a viselkedésében és kinézetében is kutyára hasonlító Colorado két férfinez füződő kapcsolata. Coloradót Quinteros küldi a címbeli házba, hogy felügyeljen Díaz Grey-re és Mollyra. Amikor Molly visszatér Quinterossal a városba, Colorado és az orvos közösen felgyújtják a házat.

Colorado tehát egyrészről Quinteros érdekeinek képviselőjeként jelenik meg, másrészt viszont sok rokon vonást mutat az orvossal is. Az összehasonlitás természetesen csak úgy lehetséges, ha figyelembe vesszük, hogy az „én” különböző szinteken történő megnyilvánulásairól van szó.

Az aktánsi viszonyok tehát két háromszög - Díaz Grey-Molly-Quinteros és Díaz Grey-Quinteros-Colorado - mentén határozhatók meg.

$\mathrm{Az}$ idő érzékelése, több más Onetti műhöz hasonlóan, itt is elsőrangú szerepet tölt be. Az események látszólagos időrendisége valójában időtlenséget takar: ennek célja a Mollyval való szerelem pillanatainak örökkévalóvá tétele.

Az elbeszélésben leggyakrabban előforduló motívumok - tüz, gyürü, homok is az időt és az elmúlást, a sors befolyásolásának lehetetlenségét sugallják. 
Onetti ezen irásában is kifejezésre jutnak a Kierkegaarddal sok rokon vonást mutató egzisztencialista filozófiájának főbb gondolatai, melynek kiindulópontja a kétségbeesés állapotának meghatározása. Díaz Grey a kétségbeesettek azon csoportjához tartozik, amely tisztában van létezésének korlátjaival. Az emlékkel való játék saját énjébe történő mind mélyebb behatolást szolgálja.

Az elbeszélés előzményeként a La vida breve címủ regény szolgált, az epilógust az 1976-ban íródott Dejemos hablar al viento (Hagyjuk a szelet beszélni) címủ müben találjuk. A képzeletbeli város, Santa María, amelynek Díaz Grey is lakója volt, elpusztul: Colorado felgyúutja, ugyanúgy, ahogy azt a homoki házzal tette. 